\title{
En svensk Brokeback Mountain
}

Holmqvist, Kalle Frans och Lars: Kärlek och klasskamp på 1890-talet.

Lund: Sekel bokförlag 20I2 (I53 sidor)

UNDER FÖRARBETET TILL den stora boken Sympatiens hemlighetsfulla makt (1999) under 1980-talet gjorde forskaren Fredrik Silverstolpe intressanta fynd rörande ett kriminalmål i Stockholm i augusti i 897, då de båda arbetarna Frans Albert Pettersson och Lars Konrad Johansson anklagades för "otukt mot naturen". Detta var något som knappast tidigare blivit belagt i Sverige: ett tio år långt, uppenbarligen homosexuellt och monogamt kärleksförhållande mellan två "vanliga", traditionellt maskulina arbetare, den ene en $4 \mathrm{I}$-årig grovarbetare med kraftigt skägg, den andre en tio år yngre måleriarbetare. De överraskades mitt $i$ ett samlag på Ekbacken intill Ladugårdsgärdet av två nyfikna gardister klockan sex på kvällen. För de stamanställda gardisterna var sexuella kontakter mellan män ingenting nytt; många av deras kamrater brukade dryga ut lönen genom att prostituera sig, en tradition som skulle fortsätta ända fram till ı9oo-talets mitt. De förstod därför av vilket skäl de båda männen drog sig in i buskarna på kullen och fann dem med neddragna byxor, Lars ovanpå Frans. På frågan vad de höll på med blev svaret obesvärat: "Vi hålla på och knulla." När gardisterna "förebrådde Pettersson och Johansson deras onaturliga förfarande, svarade de att 
detta var en sak, som ej anginge dem". Gardisterna blev tydligen sura och tog med sig arbetarna, som godvilligt följde med, för att hitta en polis som de överlämnade dem vidare till.

Vid polisförhöret och den följande rättegången berättade Frans och Lars att de lärt känna varandra tio år tidigare, då Lars arbetade i ett hus på Stora Nygatan där Frans bodde. Lars brukade sova över hos Frans, då de låg nakna i Frans säng, och ingen av dem kunde påminna sig vem som först tagit initiativet till ett sexuellt förhållande. Några år senare var de samboende i en lägenhet på Kindstugatan 9 och brukade då alltid ligga nakna tillsammans i samma säng. De turades om att sätta på varandra utan att ta några fasta roller som aktiv och passiv. Under hela deras mångåriga förhållande hade de aldrig haft några sexuella aktiviteter med andra män, tydligen inte heller med kvinnor.

Detta var alltså den historia Silverstolpe upptäckte. Sedan han blivit sjuk och inte kunde slutföra arbetet med Sympatien... övertog Greger Eman delar av hans material, och behandlade då episoden med Frans och Lars mer kortfattat i sitt kapitel om likakönade kontakter mellan arbetare. Även webbsidan Stockholmskällan tog på grundval av texten i Sympatien... upp förhållandet, och publicerade bland annat de dåliga xeroxkopior av polisfotona av Frans och Lars som användes däri, eftersom förlaget inte lyckades återfinna de av Silverstolpe lånade originalbilderna.

Kalle Holmqvist, socialistisk skribent liksom Fredrik Silverstolpe, beslöt sig för att söka djupare kring det gamla rättsfallet. I boken Frans och Lars: Kärlek och klasskamp på 1890-talet ger han en utförlig presentation av de båda huvudpersonerna och deras omvärld, kombinerat med en bred social skildring av verkligheten för den samhällsklass de tillhörde. Det är naturligtvis näraliggande att, som Holmqvist själv gör, dra en parallell till det liknande paret i novellen och filmen Brokeback Mountain. Holmqvist redogör också för synen på homosexualitet och likakönade förhållanden genom seklen, och framhåller helt riktigt att det naturligtvis funnits människor som levt och praktiserat på det sätt vi idag kallar för homosexuellt långt innan begreppet "homosexuell" fanns (det har å andra sidan i så gott som alla kulturer funnits 
olika slags benämningar som mer eller mindre motsvarar detta).

Det Holmqvist bland annat redovisar är det kända förhållandet att homosexualitet aldrig varit särskilt starkt tabubelagt inom arbetarklassen eller på landsbygden, varifrån både Frans och Lars kom. De stamanställda kände sig uppenbarligen inte moraliskt störda av att regelbundet ställa upp som prostituerade med andra män, vilket visar att man i viss utsträckning såg sexuell tillfredställelse i olika former som något naturligt och okomplicerat. Som Holmqvist påvisar blev Frans och Lars inte utstötta av sina familjer eller sina arbetskamrater, vare sig före eller efter domen. Lars tycks dock ha gett upp livet som homosexuell och gifte sig I900 med en kvinna som han året innan fått ett barn med. Det var länge inte ovanligt för bögar att på äldre dagar gifta sig med en kvinna för att få en familj - Eugène Janssons mångårige pojkvän Knut Nyman gifte sig t.ex. I9I3 sedan förhållandet med den äldre konstnärsvännen upphört, ett äktenskap som dock blev barnlöst. Frans föredrog att leva ogift, även om vi inte vet om han möjligen senare hade något förhållande med den arbetskamrat som han delade bostad med.

Kalle Holmqvists bok om Frans och Lars kan varmt rekommenderas, inte bara för den djupstudie kring kärleksparet som han presenterar utan även för hans breda och insiktsfulla skildring av deras sociala miljö.

GÖRAN SÖDERSTRÖM 